\title{
16. The Impact of FDI on China's Regional Economic Growth
}

\section{Chunlai Chen}

\section{Introduction}

Since late 1978, with the implementation of market-oriented economic reform, inward foreign direct investment (FDI) has been encouraged in China. As a consequence, foreign firms have been attracted by the huge domestic market and pool of relatively well-educated, low-cost labour, which has made China one of the most attractive destinations for FDI in the world. By the end of 2013, China had attracted a total of US\$1.4 trillion in FDI inflows, making it the largest FDI recipient in the developing world.

What are the impacts of FDI on China's economic growth? It is expected that FDI brings into a host country a package of capital and firm-specific intangible assets and, as a result, it plays a positive role in the economic development process of a host country (Caves 1996; Dunning 1993; Markusen and Venables 1999; UNCTAD 1999, 2004). In the past three decades of remarkable economic growth, FDI has contributed greatly to China's economy in terms of capital formation, employment creation and export expansion (Chen 2011). The main interest in this chapter is to investigate and identify empirically how FDI has contributed to China's regional economic growth.

Using a panel dataset containing China's 30 provinces $^{1}$ over the period 19872010 , this chapter estimates an augmented growth model in which direct effects (for example, raising output and productivity through capital augmentation and technological progress) and indirect effects (for example, improving productivity and efficiency through spillover effects on the local economy) of FDI on China's regional economic growth are analysed. The chapter first examines the impacts of FDI on China's regional economic growth by using the full sample of China's 30 provinces. Then the chapter examines how the local economic and technological conditions of host provinces influence the extent to which FDI contributes to local economic growth by subdividing China's 30 provinces into different province groups based on their economic and technological conditions.

1 Mainland China has 31 provinces. In this study, Tibet is excluded from the empirical regression analysis because of a lack of data on FDI inflows. 
The chapter finds that FDI has contributed to China's economic growth directly through capital augmentation and technological progress and indirectly through knowledge spillovers on the local economy. The chapter also finds that the contribution of FDI to economic growth is influenced by local economic and technological conditions. FDI has a stronger impact on economic growth through capital augmentation and technological progress in the developed provinces than in the less-developed provinces. While FDI has a positive and significant impact on economic growth through knowledge spillovers in the developed provinces, the positive knowledge spillovers of FDI on economic growth are absent in the less-developed provinces.

This chapter makes three contributions to the literature on the impacts of FDI on China's economic growth. First, the empirical specifications used in this chapter not only include direct effects of FDI, but also enable us to examine the spillover effects of FDI on China's regional economic growth. Second, by subdividing provinces into different groups in the estimations we can examine empirically how provincial differences in economic and technological conditions affect the extent to which the spillover effects of FDI contribute to provincial economic growth. Third, this chapter extends the period of the panel dataset to 2010, which is the most recent period in existing studies.

The structure of the chapter is as follows. The next section discusses the theoretical explanations of how FDI contributes to developing host countries' economic growth and presents a brief literature review on how the economic and technological conditions of a recipient economy influence the extent to which FDI contributes to economic growth. The third section sets out the framework of analysis and specifies the empirical model. The fourth section describes the variables and the data. The fifth section presents the results from the regressions and explains the estimation results. The final section provides the conclusion and policy implications.

\section{FDI and economic growth: theory and literature}

The role of FDI in economic growth has different explanations under different growth models. In the neoclassical growth models, which emphasise technological progress, the long-run growth can only be achieved by technological progress that is considered to be exogenous. Therefore, FDI as a source of capital input would only affect output growth in the short run. In the long run, under the conventional assumption of diminishing returns to capital inputs with a given technology, FDI would have no permanent impact on output growth. FDI, however, brings into the host country a package of not only capital, but also 
technology, production knowhow and management skills (Caves 1996; Dunning 1977, 1993), which are exogenous to the developing countries. Therefore, under the interpretation of the neoclassical growth models, a positive relationship between FDI and long-run economic growth in developing countries should be expected. In the new growth models, which emphasise the role of science and technology, human capital and externalities in economic development, FDI is treated as one of the factor inputs along with labour and domestic capital and is expected to promote growth in the long run.

To understand how FDI contributes to developing countries' economic growth, it is necessary to compare the different roles of FDI and domestic investment in the economic growth process. Domestic investment is a necessary condition for production growth and technical progress, but it may not enable a developing economy to take advantage of advanced technologies available in the developed world. FDI is different from domestic investment in three important aspects although both can be treated as a basic physical input in the production process.

First, FDI accelerates the speed of adoption of general-purpose technologies in the host countries. The general-purpose technologies are technological inventions that affect the entire system in the global economy. The most recent examples of general-purpose technologies include the computer, Internet and mobile phone. Each general-purpose technology is capable of raising the aggregate productivity of labour and capital, but it takes a considerable amount of time for all countries, especially developing countries, to explore its potential. The developed countries tend to be frontrunners in the adoption of general-purpose technologies and their experiences can be diffused through the developing economies through FDI (Yao and Wei 2007).

Second, according to Dunning's 'ownership-location-internalisation' (OLI) explanation for FDI (Dunning 1977, 1993), for multinational enterprises (MNEs) to have a strong motive to undertake direct investment aboard, they must possess certain ownership advantages. It could be a product or production process, like a patent or blueprint. It could also be some specific intangible asset or capability, like technology and information; managerial, marketing and entrepreneurial skills; organisational systems; or access to intermediate or final goods markets. The ownership advantage confers some valuable market power or cost advantage on the firm sufficient to outweigh the disadvantages of doing business abroad. In addition, MNEs must have an advantage of internalising business activities, and at the same time, the foreign market must offer a location advantage that makes it profitable to produce the product in the foreign country rather than simply produce it at home and export it to the foreign market. Therefore, FDI is embedded with new technologies, knowhow, management skills and other intangible proprietary assets and information unavailable in 
the host countries. Such advanced technologies will be able to shift the host country's production frontier to a new level so that the same amount of material inputs can lead to a higher level of output.

Third, the ability of MNEs to combine the three advantages implies that they should be able to outperform indigenous firms in production. FDI may generate positive spillovers to host countries' economic growth through three channels. First, FDI can generate horizontal positive spillovers to domestic firms in improving productivity through demonstration effect and competition, which may improve host countries' total factor productivity (TFP). Second, FDI can generate vertical positive spillovers by strengthening domestic industrial linkages through the client and supplier networks, which will improve the productivity of domestic firms in the upstream and downstream industries. Third, FDI can generate positive spillovers through passing information to host countries about international markets, best business practice and the advancement of global technological innovation, thus facilitating host countries to adjust to the changes in the world economy, increasing the competitiveness of domestic firms in global markets. Therefore, through the knowledge spillovers such as learning by doing or learning by watching (demonstration effects), research and development (R\&D), human resource movement, training courses, vertical industrial linkages, technical assistance and exposure to fierce competition, FDI can generate spillovers to improve the productivity and efficiency of local firms, thus shifting the production frontier of a host country.

The role of FDI in economic growth has been extensively studied in the literature. In the case of China, for example, Chen et al. (1995) find that FDI has been positively associated with economic growth and the increase of total fixed investment in China. Dees (1998) finds evidence supporting the view that FDI affects China's growth through the diffusion of knowledge and ideas. More recently, $\mathrm{Vu}$ et al. (2008), using sectoral FDI inflow data, evaluate the sector-specific impact of FDI on growth in China. The study finds that FDI has a statistically significant positive effect on economic growth, operating both directly and through its interaction with labour. The study also finds that the effects seem to be very different across economic sectors, with most of the beneficial impact concentrated in manufacturing industries. Tang et al. (2008) investigate the causal link between FDI, domestic investment and economic growth for the period 1988 to 2003. They find that FDI complements rather than crowding out domestic investment. As a result, FDI has not only assisted in overcoming shortage of capital, it has also stimulated economic growth through complementing domestic investment in China. Tuan et al. (2009) investigate the role inward FDI plays in the process of regional development and the channels through which economic growth would be affected by using city-level (cities in the Yangtze River Delta and the Pearl River Delta) panel dataset estimations for 
the period since China's economic opening and reform. While the study finds that FDI exerted spillover effects and affected TFP growth of the recipients, major technology and knowledge-related factors including R\&D and human capital also played critical roles in TFP enhancement and regional growth. Whalley and Xin (2010) investigate the contribution of inward FDI to China's recent rapid economic growth using a two-stage growth accounting approach. After decomposing the Chinese economy into FDI and non-FDI sectors, the study's results indicate that China's foreign-invested enterprises may have contributed more than 40 per cent of China's economic growth in 2003 and 2004, and without this inward FDI, China's overall GDP growth rate could have been around 3.4 percentage points lower.

While empirical studies have found positive effects of inward FDI on host countries' economic growth, they also reveal that the strength of the positive effects of FDI on host countries' economic growth is dependent on the economic and technological conditions in host countries. For example, in an evaluation of the impact of FDI-induced technological change on growth in developing countries, Blomstrom et al. (1992) find that the positive and statistically significant impact of FDI is stronger the higher is the level of economic development in a host country. Borensztein et al. (1998) highlight the twin roles of the introduction of advanced technology and the degree of absorptive capability in the host country as determinants of economic growth. They find that FDI is more productive than domestic investment only when the host country has a minimum threshold stock of human capital. De Mello (1997) argues that an increase in the productivity of FDI can only be achieved if there is already a sufficiently high level of human capital in a recipient economy. In an investigation of the impact of FDI on local TFP, de Mello (1999) finds that FDI exerted a positive impact on TFP only for technological leaders, while a negative relationship arose between FDI and TFP for technological followers.

In the case of China, Wei (1996) finds statistical evidence that FDI is positively associated with cross-city differences in growth rates. In a study investigating provincial economic differences and the FDI-growth relationship in China, Buckley et al. (2002) find that the growth-promoting effects of FDI are evident in the developed rather than in the less-developed provinces and that the full benefits of FDI are realised when competition in local markets is at its strongest. Yao and Wei (2007) find that FDI has a positive and significant impact on China's economic growth both as a mover of production efficiency and as a shifter of the production frontier, and the positive impact of FDI on economic growth is larger in the east than in the central and western regions. Chen (2013), using a panel dataset containing 30 Chinese provinces over the period 1987-2005, finds that FDI has contributed to China's economic growth; however, the contribution is influenced by local economic and technological conditions. FDI has a stronger 
impact on economic growth through capital augmentation and technological progress in the eastern developed provinces than in the central and western, less-developed provinces. While FDI has a positive and significant impact on economic growth through knowledge spillovers in the eastern developed provinces, knowledge spillovers of FDI on economic growth are absent in the central and western, less-developed provinces.

The above findings provide empirical evidence and support that FDI brings into the host countries a package of resources that promotes economic growth. The findings also suggest that the way in which FDI affects economic growth depends on the economic and technological conditions in a host country. In other words, the economic and technological conditions of a recipient economy influence the extent to which FDI contributes to growth.

Systematic analysis on the mechanism through which FDI contributes to the economic growth process of a developing economy has not however, been well established and studied. In China, most previous studies only investigated the direct impact of FDI as a capital input to China's economic growth; the roles of FDI on economic growth from technological progress and spillover effects are overlooked. Although a few studies examined the spillover effects of FDI on economic growth, they failed to investigate the roles of FDI on economic growth through capital augmentation and technological progress. In addition, in the studies of the role of FDI on China's regional economic growth, most grouped the provinces and regions based on geographical location and administrative division, which overlooked the differences in economic and technological conditions between provinces. China is a large country with enormous contrasts in geographical and natural conditions between provinces, and also substantial differences in the degree of economic and technological development across provinces are manifested in per capita income, human capital, R\&D capability and the level of infrastructure. These differences between provinces may influence the extent to which FDI contributes to local economic growth.

Therefore, in this chapter we would like to examine empirically the role of FDI on China's economic growth from three channels - capital augmentation, technological progress and spillover effects - with a particular emphasis on how the impact of FDI, especially the spillover effects of FDI, on economic growth are affected by regional differences in China at the provincial level. 


\section{Analytical framework and the empirical model}

We estimate the impact of FDI on China's provincial economic growth by specifying an aggregate production function as follows (Equation 16.1).

Equation 16.1

$$
Y_{i t}=A_{i t} L_{i t}^{\beta_{1}} D K_{i t}^{\beta_{2}} F K_{i t}^{\beta_{3}}
$$

In Equation 16.1, $\mathrm{Y}_{\mathrm{it}}$ is the real gross domestic product (GDP) of province $\mathrm{i}$ in year $t$; $A_{i t}$ is the TFP level of province $i$ in year $t$; $L_{i t}$ is the total labour input of province $\mathrm{i}$ in year $\mathrm{t}$; $\mathrm{DK}_{\mathrm{it}}$ is the domestic capital stock of province $\mathrm{i}$ in year $\mathrm{t}$; and $\mathrm{FK}_{\mathrm{it}}$ is the foreign capital stock of province $\mathrm{i}$ in year $\mathrm{t}$.

In this specification, FDI is treated as a separate factor of capital input (FK) along with domestic capital input (DK) and labour input (L) in the aggregate production function.

Theoretically, because FDI brings into the host country a package of capital, technology, production knowhow, management skills, marketing skills and information, competition and so on (Caves 1996; Dunning 1993), it is expected that FDI can increase the host country's economic growth by a number of means.

First, the inflows of FDI will increase demand for labour and create employment in a host country, especially in developing countries. The increase in employment will contribute to an increase in total output, thus leading to a movement of output to a higher level along the existing production function. This positive effect of FDI on output growth is the contribution of FDI through employment creation, which can be expressed as $\partial Y / \partial L_{F K}>0$, implying that the higher the employment created by FDI, the higher is the output growth of a host economy.

Second, the inflows of FDI increase a host country's fixed capital formation. Through capital augmentation in a recipient economy, FDI is expected to be growth enhancing by encouraging the incorporation of new inputs and technologies into the production function, thus shifting the production function of a host country. This positive shifting effect of FDI is the contribution of FDI as a capital input to output growth, which can be expressed as $\partial Y / \partial F K>0$, implying that the higher the foreign capital input, the higher is the output growth of the host economy.

Third, FDI is believed to be a leading source of technology transfer and human capital augmentation in developing countries. Technological progress takes place through a process of capital deepening in the form of the introduction of new varieties of knowledge-based capital goods. It also proceeds via specific 
productivity-increasing labour training and skill acquisition promoted by MNEs. Therefore, FDI is expected to shift the production function of a host country over time as a result of technological progress. This positive shifting effect of FDI is the contribution of technology progress to output growth, which can be expressed as $\partial Y / \partial F K=f(t)>0$, implying that the marginal product of foreign capital is an increasing function of time.

Fourth, through the knowledge spillovers such as learning by doing or learning by watching (demonstration effects), $\mathrm{R} \& \mathrm{D}$, human resource movement, training courses, vertical industrial linkages, technical assistance and exposure to fierce competition, FDI is expected to increase the productivity and efficiency of the local firms of a host country. As a result, through knowledge spillovers, FDI can shift the production function of a host economy to a higher level. This positive shifting effect of FDI is the spillover effect on the local economy, which can be expressed as $\partial Y / \partial S F K>0$, implying that the higher the presence of FDI, the higher are the spillover effects of FDI on local economic growth.

With the above propositions, the TFP, $\mathrm{A}_{\mathrm{it}}$ can be defined as Equation 16.2.

Equation 16.2

$$
A_{i t}=B_{i t} e^{g\left(t, t^{*} F K_{i t}, S F K_{i t}, Z\right)}
$$

In Equation 16.2, $\mathrm{A}_{\mathrm{it}}$ is the TFP level of province $\mathrm{i}$ in year $\mathrm{t} ; \mathrm{B}_{\mathrm{it}}$ is the residual TFP level of province $i$ in year $t$; $t$ is a time trend, which captures the Hicks-neutral technological progress in province $i$ in the absence of FDI or foreign technology; $\mathrm{t}^{*} \mathrm{FK}_{\mathrm{it}}$ captures the additional technological progress that is attributed only to FDI; $\mathrm{SFK}_{\mathrm{it}}$ is the presence of FDI in province i in year $t$, which captures the spillover effects of FDI; $Z$ is a set of other variables that can also improve productivity. One such variable is human capital (HK). It has been suggested in recent growth models as a determinant of growth (for example, Barro and Sala-i-Martin 1995; Levin and Raut 1997). In particular, these models predict a positive impact of human capital on economic growth.

Incorporating Equation 16.2 into the aggregate production function Equation 16.1, by taking the natural logarithm of the variables of labour (L), domestic capital (DK) and foreign capital (FK) in the production function, adding the variable of human capital (HK) to control the impact of human capital, and rearranging the items on the right-hand side, with the addition of a constant $\operatorname{term}\left(\beta_{0}\right)$ and an error term $\left(\varepsilon_{\mathrm{it}}\right)$, we obtain the empirical regression Equation 16.3.

\section{Equation 16.3}

$$
\operatorname{LnY}_{i t}=\beta_{0}+\beta_{1} \operatorname{LnL}_{i t}+\beta_{2} \operatorname{LnDK}_{i t}+\beta_{3} \operatorname{LnFK}_{i t}+\beta_{4} t+\beta_{5} t^{*} \operatorname{LnFK}_{i t}+\beta_{6} S K_{i t-1}+\beta_{7} H_{i t}+\varepsilon_{i t}
$$


In Equation 16.3, $\mathrm{i}(\mathrm{i}=1,2, \ldots, 30)$ and $\mathrm{t}(\mathrm{t}=1987, \ldots, 2010)$ denote province $\mathrm{i}$ and year t; L and DK are labour and domestic capital stock; ${ }^{2} \mathrm{FK}$ is foreign capital stock, which captures the contribution of FDI to economic growth through capital augmentation; $\mathrm{t}$ is a time trend, which captures the Hicksneutral technological progress in the absence of FDI or foreign technology; the interaction term $t^{*} \mathrm{LnFK}$ captures the additional technological progress to economic growth that is attributed only to FDI; SFK is the presence of FDI (share of foreign capital stock to total capital stock), which captures the spillover effects of FDI to economic growth through improving the productivity and efficiency of the local economy; and HK is human capital.

This empirical model allows us to test the impact of FDI on China's provincial economic growth in three respects. First, we can test the direct contribution of FDI to provincial economic growth. If the coefficient $\beta_{3}$ is positive and statistically significant then FDI has directly contributed to provincial economic growth through capital input. Second, we can test the effect of technological progress of FDI on provincial economic growth. If the coefficient $\beta_{5}$ is positive and statistically significant then there is evidence that FDI has contributed to provincial economic growth through technological progress. Third, we can test the spillover effects of FDI on provincial economic growth. If the coefficient $\beta_{6}$ is positive and statistically significant then there is evidence that FDI has generated positive spillover effects - for example, diffusion of technology and management skills to the local economy, thus promoting provincial economic growth.

Equation 16.3 is the form of an augmented production function model that we will use to estimate the impact of FDI on China's provincial economic growth. The first part of the analysis is to examine the role of FDI on provincial economic growth through the three channels of capital augmentation, technological progress and spillover effects by using the full sample of China's 30 provinces. The second part of the analysis is to examine the impact of FDI on the economic growth of different provincial groups by using the sub-samples of province groups based on their economic and technological conditions in order to investigate whether local economic and technological conditions influence the extent to which FDI contributes to local economic growth. The following section will describe the variables and the data.

2 Official data for labour employed by FDI at the provincial level are not available. So, the total number of labour of each province is used in the regression. 


\section{Variable specification and the data}

The data for provincial gross domestic product $(\mathrm{Y})$ and provincial total capital stock are from Wu (2009). ${ }^{3}$ Wu uses the conventional perpetual inventory method by employing the recently released national accounts figures to derive a capital stock series for China's 31 provinces and three economic sectors (that is, agriculture, manufacturing and services) for the period 1977-2010. This is one of the most comprehensive datasets of capital stock series for China's 31 provinces and three economic sectors.

The data for FDI stock (FK) are calculated in several steps. First, the US dollar value of annual FDI inflows is converted into renminbi value by using the annual average official exchange rate. Second, the renminbi value of annual FDI inflows is deflated into the real value at 1978 prices by using China's national consumer price index (CPI). Third, a 5 per cent depreciation rate is assumed for foreign capital (FDI). Finally, FDI stock is accumulated for each year end measured as billion renminbi at 1978 prices. The hypothesis is that provinces with a larger FDI stock will have higher expansion in production and higher technological progress over time, thus shifting the production frontier and accelerating provincial economic growth.

The domestic capital stock (DK) of each province is obtained by deducting the FDI stock (FK) from the total capital stock. Labour (L) is the total number of employed persons in each province measured as one million persons.

The presence of FDI is measured as the share of FDI stock in the total capital stock of a province (SFK) to capture the spillover effects of FDI on local economic growth. It is reasonable to assume that FDI inflows and spillover effects from FDI have a time lag, so the value of a one-year lag of SFK is used in the model. The use of the lagged value of SFK also can avoid the endogeneity problem in the regression. The hypothesis is that provinces with a higher share of FDI stock in total capital stock will have higher spillover effects from FDI to the local economy, thus increasing the productivity and efficiency of local firms and promoting provincial economic growth.

In this chapter human capital (HK) is measured as the ratio of the number of university students to the total population of each province. We expect the human capital to be positively related to the economic growth of the host province. The dependent and independent variables and the data sources are summarised in Table 16.1.

3 Data for 2007-10 are provided by Wu (2009). 
Table 16.1 Variables of the Impact of FDI on China's Provincial Economic Growth

\begin{tabular}{|c|c|c|}
\hline Variable name & Specification of variables & Sources \\
\hline \multicolumn{3}{|c|}{ Dependent variable } \\
\hline$Y_{i t}$ & $\begin{array}{l}\text { Gross domestic product of } \\
\text { province } \mathrm{i} \text { in year t. Billion RMB } \\
\text { at } 1978 \text { prices. }\end{array}$ & $\begin{array}{l}\text { Wu (2009) and China Statistical } \\
\text { Yearbook (NBS various years). }\end{array}$ \\
\hline \multicolumn{3}{|c|}{ Independent variables } \\
\hline $\mathrm{L}_{\text {it }}$ & $\begin{array}{l}\text { Total number of employed } \\
\text { persons of province } \mathrm{i} \text { in year } \mathrm{t} \text {. } \\
\text { Million persons. }\end{array}$ & $\begin{array}{l}\text { China Statistical Yearbook (NBS } \\
\text { various years). }\end{array}$ \\
\hline $\mathrm{DK}_{\mathrm{it}}$ & $\begin{array}{l}\text { Domestic capital stock of } \\
\text { province } \mathrm{i} \text { in year t. Billion RMB } \\
\text { at } 1978 \text { prices. }\end{array}$ & $\begin{array}{l}\text { Calculated from Wu (2009) and } \\
\text { various issues of China Statistical } \\
\text { Yearbook (NBS various years). }\end{array}$ \\
\hline $\mathrm{FK}_{\mathrm{it}}$ & $\begin{array}{l}\text { FDI stock of province } \mathrm{i} \text { in year } \mathrm{t} \text {. } \\
\text { Billion RMB at } 1978 \text { prices. }\end{array}$ & $\begin{array}{l}\text { Calculated from various issues of } \\
\text { China Statistical Yearbook (NBS } \\
\text { various years) and the Annual } \\
\text { National Economic Report (NBS } \\
\text { various years) of each province. }\end{array}$ \\
\hline SFK $_{\text {it-1 }}$ & $\begin{array}{l}\text { Share of FDI stock in total capital } \\
\text { stock of province i in year } t-1 \text {. } \\
\text { Per cent. }\end{array}$ & Same as above. \\
\hline $\mathrm{HK}_{\mathrm{it}}$ & $\begin{array}{l}\text { Human capital of province } \mathrm{i} \text { in } \\
\text { year } \mathrm{t} \text { measured as the ratio of } \\
\text { the number of university students } \\
\text { to total population. Per cent. }\end{array}$ & Same as above. \\
\hline
\end{tabular}

Source: Author's own description.

\section{Regression results and explanations}

\section{The impact of FDI on economic growth: all provinces}

The data used in the regression are a panel dataset at the provincial level, containing China's 30 provinces over the period 1987 to $2010 .{ }^{4}$ We first conduct a Hausman test to choose between the random-effects model and the fixed-effects model for the regression. The Hausman test prefers the fixed-effects model. Therefore, we estimate Equation 16.3 under the fixed-effects model in order to eliminate the province-specific and time-invariant factors that may affect economic growth. For a robustness check, we also report the regression results under the random-effects model. The two models performed very well. All of the independent variables have the expected signs and are statistically significant at

4 Tibet is excluded from the sample because of a lack of data. 
the 1 per cent level (except the variable of LnFK, which is statistically significant at the 10 per cent level in the fixed-effects model), and the models have high explanatory power. The regression results are reported in Table 16.2.

The regression results show that labour input (L) and domestic capital stock (DK) are positive and statistically significant at the 1 per cent level, indicating the significant contributions of labour and domestic capital inputs to provincial economic growth.

For the variables of our main interest-LnFK, $t^{*}$ LnFK and SFK- the coefficients are positive and statistically significant in both regressions. These results provide strong support for the propositions discussed in section three.

Table 16.2 Regression Results of Production Function of All Provinces, 1987-2010

\begin{tabular}{|l|r|r|}
\hline Variables & Fixed-effects model & Random-effects model \\
\hline Constant & 0.8392 & -0.0386 \\
& $(5.94)^{* * *}$ & $(-0.36)$ \\
\hline LnL & 0.2665 & 0.4600 \\
& $(7.03)^{* * *}$ & $(17.60)^{* * *}$ \\
\hline LnDK & 0.3456 & 0.4407 \\
& $(15.75)^{* *}$ & $(20.13)^{* *}$ \\
\hline LnFK & 0.0098 & 0.0235 \\
\hline T & $(1.82)^{*}$ & $(4.16)^{* *}$ \\
\hline T*LnFK & 0.0539 & 0.0376 \\
& $(20.85)^{* * *}$ & $(16.46)^{* *}$ \\
\hline SFK & 0.0022 & 0.0013 \\
& $(6.59)^{* * *}$ & $(3.74)^{* * *}$ \\
\hline HK & 0.0163 & 0.0199 \\
& $(9.01)^{* * *}$ & $(10.31)^{* * *}$ \\
\hline No. of observations & 0.0574 & 0.0974 \\
\hline No. of groups & $(4.16)^{* *}$ & $(6.79)^{* * *}$ \\
\hline R $^{2}$ overall & 710 & 710 \\
\hline & 30 & 30 \\
\hline
\end{tabular}

* Statistically significant at 0.10 level (two-tail test).

** Statistically significant at 0.05 level (two-tail test).

*** Statistically significant at 0.01 level (two-tail test).

Source: Author's own estimations.

Note: t-statistics are in parentheses.

First, the variable of foreign capital stock (LnFK) is positive and statistically significant at the 10 per cent level in the fixed-effects model and at the 1 per cent level in the random-effects model, which provides support that FDI as a factor of 
capital input directly contributes to provincial economic growth. The estimation results imply that provinces with higher FDI inflows will have higher economic growth contributed directly by the increase in foreign capital input.

Second, the interaction term of a time trend and the FDI stock ( $\left.t^{*} \operatorname{LnFK}\right)$ is positive and statistically significant at the 1 per cent level in both regressions, which supports the proposition that FDI shifts the domestic production frontier through technological progress. The regression results show that over time, FDI helps the domestic economy to move continuously onto a higher steady-state technology. This change in the domestic production frontier caused by FDI is an additional enforcement of the Hicks-neutral technological progress represented by the coefficient on a time trend $(\mathrm{t})$, which is positive and statistically significant at the 1 per cent level in both regressions.

Third, the variable of the spillover effects of FDI - the share of FDI stock in total capital stock (SFK) - is positive and statistically significant at the 1 per cent level in both regressions. This is consistent with the hypothesis that FDI has positive spillover effects on provincial economic growth through improving the productivity and efficiency of the local economy. Thus, the regression results have provided strong empirical evidence to support the hypothesis that FDI inflows into China together with a package of knowledge-based firm-specific assets have produced positive spillover effects on China's provincial economic growth. The estimation results imply that provinces with a higher share of FDI stock in total capital stock will have higher spillover effects from FDI to the local economy, thus improving the productivity and efficiency of the local economy and raising provincial economic growth.

Finally, the variable of human capital (HK) is positive and statistically significant at the 1 per cent level in both models, which provides empirical evidence that human capital contributes to economic growth.

\section{The impact of FDI on economic growth: by region}

China is a large country with enormous contrasts in geographical and natural conditions between provinces, and also substantial differences in the degree of economic and technological development in terms of per capita income, human capital and R\&D capability, and the level of infrastructure across provinces. While an overall positive impact of FDI on economic growth is revealed in the above empirical analysis, the large disparity in economic and technological conditions across provinces could mean that the impact of FDI on economic growth is different between regions. To investigate the impact of regional differences on the role of FDI in economic growth, we subdivide the full sample of 30 provinces into three pairs of mutually exclusive groups based on their economic, technological and infrastructure conditions - namely: 1) the high 
and low economic development province groups; 2) the high and low human capital and R\&D capability province groups; and 3) the high and low level of infrastructure province groups.

The economic development level is a comprehensive economic and social indicator of a province. A higher economic development level not only indicates good overall economic performance but also implies higher productivity associated with higher labour quality, higher research and innovation capability, advanced technology and better conditions of local infrastructure. In this chapter, we use per capita GDP as a proxy for the provincial economic development level. Provinces with per capita GDP above the national average are classified as the high-income provinces; otherwise they are classified as the lowincome provinces. We expect that FDI will have a higher impact on economic growth in the high-income provinces than in the low-income provinces.

Studies of FDI and economic growth postulate a positive link between FDI and human capital and R\&D capability, since the application of the advanced technology embodied in FDI requires a sufficient level of human capital and R\&D capability in host countries. Therefore, the level of human capital and R\&D capability not only indicates the ability of scientific and technological innovation and progress of an economy, but also reveals the absorptive capability of the host economy. We assume that economies with a higher level of human capital and R\&D capability will find it much easier to absorb advanced technology and management skills from MNEs and will facilitate and enhance the diffusion of spillovers from FDI to the local economy, thus increasing economic growth. In this chapter human capital is measured as the ratio of the number of university students to the total population of each province, and the number of patent applications per 10000 persons is used as a proxy for the level of R\&D capability of host provinces. Provinces are classified as high human capital and R\&D capability provinces if the ratio of the number of university students to the total population and the number of patent applications per 10000 persons are above the national average; otherwise they are classified as low human capital and R\&D capability provinces. We expect the impact of FDI, in particular the spillover effects of FDI, on economic growth will be stronger in the high human capital and R\&D capability provinces than in the low human capital and R\&D capability provinces.

The level of infrastructure in each province might be another important factor influencing the impact of FDI on local economic growth. We assume that better infrastructure not only is essential for FDI to be more productive but also can facilitate the diffusion of spillovers from FDI to the local economy. In this chapter two measures are used as the proxy of the level of infrastructure of a host province. One is the intensity of transport infrastructure and another is the level of telecommunications. The measure of the intensity of transport infrastructure 
is the ratio of the sum of the length of highways, railways and interior transport waterways divided by the size of the corresponding host province. The unit of the intensity of transport infrastructure is kilometres per $100 \mathrm{sq} \mathrm{km}$ of the host province's land area. The measure of the level of telecommunications is the number of telephone sets per 100 persons in each province. Provinces are classified as high-level infrastructure provinces if the intensity of transport infrastructure and the number of telephone sets per 100 persons are above the national average; otherwise they are classified as low-level infrastructure provinces. We expect that provinces with a high level of infrastructure will facilitate the diffusion of spillovers from FDI to the local economy.

For simplicity, we call the provinces with high per capita GDP, high-level human capital and R\&D capability, and high-level infrastructure the developed province groups, while the provinces with low per capita GDP, low-level human capital and R\&D capability, and low-level infrastructure the less-developed province groups. Table 16.3 presents the average value of the basic economic development indicators discussed above. From the table we can see there are large differences between the developed provinces and the less-developed provinces in terms of per capita GDP, human capital and R\&D capability, and infrastructure conditions. These provincial differences are expected to play important roles in influencing the impact of FDI on provincial economic growth.

Table 16.3 Basic Economic Development Indicators by Province Groups (year 2010)

\begin{tabular}{|l|c|c|c|}
\hline Basic economic development indicators & $\begin{array}{c}\text { National } \\
\text { average }\end{array}$ & $\begin{array}{c}\text { Average of } \\
\text { the developed } \\
\text { province groups }\end{array}$ & $\begin{array}{c}\text { Average of the } \\
\text { less-developed } \\
\text { province groups }\end{array}$ \\
\hline $\begin{array}{l}\text { Per capita GDP (RMB/person) } \\
\text { (2000 = 100) }\end{array}$ & 26525 & 41873 & 192 \\
\hline $\begin{array}{l}\text { Human capital } \\
\text { (university students/population) (\%) }\end{array}$ & 1.72 & 2.08 & 1.48 \\
\hline $\begin{array}{l}\text { Level of R\&D } \\
\text { (patent applications/10 000 persons) }\end{array}$ & 4.88 & 9.90 & 1.54 \\
\hline $\begin{array}{l}\text { Transportation intensity index } \\
\text { (km per 100 sq km) }\end{array}$ & 93 & 141 & 69 \\
\hline $\begin{array}{l}\text { Level of telecommunications } \\
\text { (phone sets/100 persons) }\end{array}$ & 89 & 113 & 77 \\
\hline
\end{tabular}

Sources: Calculated from China Statistical Yearbook (NBS various years).

We also use Equation 16.3 to conduct the empirical analysis. To eliminate the province-specific and time-invariant factors that may affect economic growth, we run the regressions under a fixed-effects model with panel data. The fixedeffects regression results for the three pairs of province groups are reported in Table 16.4. 
The regression results reveal a number of interesting findings. First, the variable of LnFK is positive and statistically significant at the 1 and 5 per cent levels in all regressions, which signifies the significant contribution of FDI to economic growth through capital augmentation.

Second, the variable of $\mathrm{t}^{*} \mathrm{LnFK}$ is positive and statistically significant at the 1 and 5 per cent levels in all regressions. This implies that FDI shifts the domestic production frontier through technological progress over time.

Third, the variable of SFK is positive and statistically significant at the 1 per cent level for the developed province groups, but is negative for the lessdeveloped province groups. This implies that local economic and technological conditions affect the diffusion of knowledge spillovers from FDI to the local economy. This finding is consistent with those of Borensztein et al. (1998), de Mello (1997, 1999) and Tuan et al. (2009).

Table 16.4 Regression Results of Production Function by Province Groups, 1987-2010 (fixed-effects model)

\begin{tabular}{|c|c|c|c|c|c|c|}
\hline \multirow[b]{2}{*}{ Variables } & \multicolumn{2}{|c|}{ Per capita GDP } & \multicolumn{2}{|c|}{ HK and R\&D capability } & \multicolumn{2}{|c|}{ Level of infrastructure } \\
\hline & High & Low & High & Low & High & Low \\
\hline Constant & $\begin{array}{r}1.0845 \\
(4.32)^{* * * *}\end{array}$ & $\begin{array}{r}1.2635 \\
(7.00)^{* * *}\end{array}$ & $\begin{array}{r}1.4476 \\
(6.21)^{* * *}\end{array}$ & $\begin{array}{r}1.0038 \\
(5.69) * * *\end{array}$ & $\begin{array}{r}2.0092 \\
(8.67)^{* * *}\end{array}$ & $\begin{array}{r}1.0837 \\
(5.82)^{* * *}\end{array}$ \\
\hline LnL & $\begin{array}{r}0.3352 \\
(5.52)^{* * *}\end{array}$ & $\begin{array}{r}0.1286 \\
(2.36)^{* *}\end{array}$ & $\begin{array}{r}0.3787 \\
(7.03)^{* * *}\end{array}$ & $\begin{array}{r}-0.0345 \\
(-0.62)\end{array}$ & $\begin{array}{r}0.2515 \\
(4.70)^{* * *}\end{array}$ & $\begin{array}{r}0.0460 \\
(0.82)\end{array}$ \\
\hline LnDK & $\begin{array}{r}0.2996 \\
(7.39)^{* * *}\end{array}$ & $\begin{array}{r}0.3095 \\
(9.56)^{* * *}\end{array}$ & $\begin{array}{r}0.2056 \\
(5.58)^{* * *}\end{array}$ & $\begin{array}{r}0.4863 \\
(15.80)^{* * *}\end{array}$ & $\begin{array}{r}0.1422 \\
(3.91)^{* * *}\end{array}$ & $\begin{array}{r}0.4250 \\
(13.70)^{* * *}\end{array}$ \\
\hline LnFK & $\begin{array}{r}0.0321 \\
(2.40)^{* *}\end{array}$ & $\begin{array}{r}0.0215 \\
(3.57)^{* * *}\end{array}$ & $\begin{array}{r}0.0284 \\
(2.47)^{* *}\end{array}$ & $\begin{array}{r}0.0371 \\
(6.06)^{* * *}\end{array}$ & $\begin{array}{r}0.0469 \\
(4.06)^{* * *}\end{array}$ & $\begin{array}{r}0.0329 \\
(5.33)^{* * *}\end{array}$ \\
\hline $\mathrm{T}$ & $\begin{array}{r}0.0548 \\
(11.53)^{* * *}\end{array}$ & $\begin{array}{r}0.0574 \\
(16.47)^{* * *}\end{array}$ & $\begin{array}{r}0.0518 \\
(11.29)^{* * *} \\
\end{array}$ & $\begin{array}{r}0.0395 \\
(11.64)^{* * *}\end{array}$ & $\begin{array}{r}0.0613 \\
(13.73)^{* * *} \\
\end{array}$ & $\begin{array}{r}0.0462 \\
(13.47)^{* * *} \\
\end{array}$ \\
\hline $\mathrm{T}^{*} \mathrm{LnFK}$ & $\begin{array}{r}0.0027 \\
(3.46) * * *\end{array}$ & $\begin{array}{r}0.0020 \\
(4.52)^{* * *}\end{array}$ & $\begin{array}{r}0.0051 \\
(6.43)^{* * *}\end{array}$ & $\begin{array}{r}0.0010 \\
(2.23)^{* *}\end{array}$ & $\begin{array}{r}0.0052 \\
(6.74)^{* * *}\end{array}$ & $\begin{array}{r}0.0015 \\
(3.15)^{* * *}\end{array}$ \\
\hline SFK & $\begin{array}{r}0.0131 \\
(4.53)^{* * *} \\
\end{array}$ & $\begin{array}{r}-0.0081 \\
(-1.42) \\
\end{array}$ & $\begin{array}{r}0.0145 \\
(5.74)^{* * *} \\
\end{array}$ & $\begin{array}{r}-0.0014 \\
(-0.24) \\
\end{array}$ & $\begin{array}{r}0.0097 \\
(4.00)^{* * *} \\
\end{array}$ & $\begin{array}{r}-0.0165 \\
(-3.12)^{* * *} \\
\end{array}$ \\
\hline HK & $\begin{array}{l}0.0367 \\
(1.70)^{*}\end{array}$ & $\begin{array}{r}0.0751 \\
(4.10)^{* * *} \\
\end{array}$ & $\begin{array}{r}0.0357 \\
(1.91)^{* *}\end{array}$ & $\begin{array}{r}0.0948 \\
(4.82) * * * \\
\end{array}$ & $\begin{array}{r}0.0196 \\
(1.08)\end{array}$ & $\begin{array}{r}0.0726 \\
(3.71)^{* *}\end{array}$ \\
\hline $\begin{array}{l}\text { No. of } \\
\text { observations }\end{array}$ & 264 & 446 & 278 & 432 & 230 & 480 \\
\hline $\begin{array}{l}\text { No. of } \\
\text { groups }\end{array}$ & 11 & 19 & 12 & 18 & 10 & 20 \\
\hline $\mathrm{R}^{2}$ overall & 0.91 & 0.84 & 0.89 & 0.82 & 0.82 & 0.84 \\
\hline F-statistics & $3474 * * *$ & $10100 * * *$ & $4304 * * *$ & $10078 * * *$ & $4320 * * *$ & $9769 * * *$ \\
\hline
\end{tabular}

* Statistically significant at 0.10 level (two-tail test).

** Statistically significant at 0.05 level (two-tail test).

*** Statistically significant at 0.01 level (two-tail test).

High - for developed province groups.

Low - for less-developed province groups.

Source: Author's own estimations.

Note: t-statistics are in parentheses. 
Fourth, the regression results provide strong empirical evidence that FDI not only directly contributes to economic growth through capital augmentation and technological progress, but also indirectly contributes to economic growth through knowledge spillovers on the local economy in the developed provinces. While the regression results also suggest that FDI can contribute to economic growth through capital augmentation and technological progress in the lessdeveloped provinces, FDI may not improve the productivity and efficiency of the local economy through knowledge spillovers in the less-developed provinces. This finding has important policy implications for regional economic development.

Fifth, comparing the province groups with high per capita GDP and highlevel infrastructure with the province groups with low per capita GDP and lowlevel infrastructure, although FDI has a positive and statistically significant impact on economic growth through capital augmentation and technological progress in all groups, the regression results do show that the coefficients of the variables of LnFK and $t^{*} \mathrm{LnFK}$ are higher in the province groups with high per capita GDP and high-level infrastructure than those with low per capita GDP and low-level infrastructure respectively. This implies that FDI has a larger impact on shifting the local production frontier to accelerate economic growth in the developed provinces than in the less-developed provinces.

Finally, there is significant difference between the developed province groups and the less-developed province groups in the values of estimated labour (L) and domestic capital (DK) elasticities. At the national level, there is no significant difference between labour elasticity and domestic capital elasticity. In the developed province groups, variables of both labour and domestic capital are positive and statistically significant; however, labour elasticity is around two to three times domestic capital elasticity, implying that the marginal product of labour is not only much higher than that of the marginal product of domestic capital in the developed province groups but also substantially more than that in the rest of the country. This also suggests that labour may be a constraint on economic growth in the developed provinces. In contrast, in the less-developed province groups, the variable of domestic capital is positive and statistically significant but the variable of labour is statistically insignificant. This implies that the marginal product of domestic capital is much higher than that of labour due to the relative abundance of labour supply and scarcity of capital in the less-developed provinces.

Referring to the differences in economic and technological conditions between the developed province groups and the less-developed province groups and the regression results, we may argue that, given the level of FDI stock, provinces with a higher level of economic development (per capita GDP), higher level of human capital and R\&D capability and higher level of infrastructure 
will facilitate and enhance the role of FDI to local economic growth through capital augmentation, technological progress and spillover effects. Thus, this chapter also provides empirical evidence to suggest that local economic and technology conditions, especially local absorptive capability, play important roles in determining the impact of FDI on economic growth and in influencing the diffusion of knowledge spillovers from FDI to the local economy.

\section{Conclusion}

The main purpose of this chapter is to investigate empirically the contribution of FDI to China's economic growth through the channels of capital augmentation, technological progress and spillover effects, with a particular emphasis on how the role of FDI on economic growth is affected by regional differences in China at the provincial level. Based on theoretical foundations, an augmented empirical growth model is specified, and a panel dataset containing China's 30 provinces over the period from 1987 to 2010 is used under the panel regression models. The chapter has provided the following main findings.

First, the regression results of all provinces provide strong evidence that FDI contributes to China's economic growth both directly through capital augmentation and technological progress and indirectly through spillover effects on the local economy. This implies that provinces with higher FDI inflows, higher foreign capital stock and a higher share of FDI stock in total capital stock have higher economic growth contributed directly by the increase in foreign capital input associated with technological progress and indirectly by the diffusion of knowledge spillovers from FDI to the local economy.

Second, the impact of FDI on economic growth is different between province groups with different economic and technological conditions. The regression results show that the contributions of FDI to economic growth are higher in the developed provinces than those in the less-developed provinces. In the developed provinces, FDI not only directly contributes to economic growth through capital augmentation and technological progress but also indirectly contributes to economic growth through spillover effects. In contrast, in the lessdeveloped provinces, FDI is found to contribute to economic growth through capital augmentation but is not found to improve the productivity and efficiency of the local economy due to the lack of knowledge spillovers. Referring to the difference in economic and technological conditions between the developed and less-developed province groups and the regression results, this finding provides empirical evidence to suggest that local economic and technological conditions, especially local absorptive capability, do matter in influencing the diffusion of knowledge spillovers from FDI to the local economy. 
Third, the provincial difference in the role of FDI on economic growth deserves attention for both policymaking and academic research. The real problem is not that FDI causes the widening gap between the developed provinces and the less-developed provinces, but that FDI has played a much larger and more significant role in the former than in the latter. As a result, policy should be designed to encourage FDI flows into the less-developed provinces. To achieve the full potential of FDI, conditions have to be created, such as investment in education and infrastructure; but other policies such as inter-regional migration and cross-regional investments are also important in reducing regional disparity in income and production.

Finally, the chapter finds that although the empirical regression results show a positive and statistically significant impact of FDI on economic growth, the magnitude of the contribution from the technological progress and spillover effects of FDI to China's economic growth was still very small. This implies that China still has a lot of benefits to gain from FDI. Therefore, apart from improving local economic and technological conditions to attract more FDI inflows, China should encourage contact, information exchange, production and technological cooperation, joint R\&D activities, industrial linkages and competition between domestic firms and FDI firms, in order to enhance and accelerate the technological progress and the diffusion of positive spillovers from FDI to China's economy.

\section{References}

Barro, R. and Sala-i-Martin, X. (1995), Economic Growth, New York: McGrawHill.

Blomstrom, M., Lipsey, R. and Zejan, M. (1992), What explains developing country growth, NBER Working Paper No. 4132, National Bureau of Economic Research, Cambridge, Mass. Available from <http://www.nber.org/papers/ w4132.pdf $>$.

Borensztein, E., Gregorio, J. and Lee, J. (1998), 'How does foreign direct investment affect growth', Journal of International Economics 45:115-35.

Buckley, P., Clegg, J., Wang, C. and Cross, A. (2002), 'FDI, regional differences and economic growth: panel data evidence from China', Transnational Corporations 2(1):1-28.

Caves, R. (1996), Multinational Enterprise and Economic Analysis, 2nd edn, Cambridge: Cambridge University Press. 
Chen, C. (2011), Foreign Direct Investment in China: Location Determinants, Investor Differences and Economic Impacts, Cheltenham, UK, and Northampton, Mass.: Edward Elgar.

Chen, C. (2013), 'FDI and Economic Growth', in Y. Wu (ed.), Regional Development and Economic Growth in China, Series on Economic Development and Growth No. 7, pp. 117-40, Singapore: World Scientific.

Chen, C., Chang, L. and Zhang, Y. (1995), 'The role of foreign direct investment in China's post-1978 economic development', World Development 23(4):691-703.

Dees, S. (1998), 'Foreign direct investment in China: determinants and effects', Economics of Planning 31(2):175-94.

de Mello, L. (1997), 'Foreign direct investment in developing countries and growth: a selective survey', The Journal of Development Studies 34(1):1-34.

de Mello, L. (1999), 'Foreign direct investment-led growth: evidence from time series and panel data', Oxford Economic Papers 51(1):133-51.

Dunning, J. (1977), 'Trade, location of economic activity and the multinational enterprise: a search for an eclectic approach', in B. Ohlin, P. Hesselborn and P. Wijkman (eds), The International Allocation of Economic Activity, pp. 395-418, London: Macmillan.

Dunning, J. (1993), Multinational Enterprises and the Global Economy, Wokingham, UK: Addison-Wesley.

Levin, A. and Raut, L. (1997), 'Complementarities between exports and human capital in economic growth: evidence from the semi-industrialized countries', Economic Development and Cultural Change 46(1):155-74.

Markusen, J. and Venables, A. (1999), 'Foreign direct investment as a catalyst for industrial development', European Economic Review 43(2):335-56.

National Bureau of Statistics of China (NBS) of each province (various years), Annual National Economic Report of each province, online sources.

National Bureau of Statistics of China (NBS) (various years), China Statistical Yearbook, Beijing: China Statistics Press. 
Tang, S., Selvanathan, E. and Selvanathan, S. (2008), 'Foreign direct investment, domestic investment and economic growth in China: a time series analysis', World Economy 31(10):1292-309.

Tuan, C., Ng, L. and Zhao, B. (2009), 'China's post-economic reform growth: the role of FDI and productivity progress', Journal of Asian Economics 20(3):280-93.

United Nations Conference on Trade and Development (UNCTAD) (1999), World Investment Report 1999: Foreign Direct Investment and the Challenge of Development, New York and Geneva: United Nations Publication.

United Nations Conference on Trade and Development (UNCTAD) (2004), World Investment Report 2004: The Shift Towards Services, New York and Geneva: United Nations Publication.

Vu, T., Gangnes, B. and Noy, I. (2008), 'Is foreign direct investment good for growth? Evidence from sectoral analysis of China and Vietnam', Journal of the Asia Pacific Economy 13(4):542-62.

Wei, S. (1996), 'Foreign direct investment in China: sources and consequences', in T. Ito and A. Krueger (eds), Financial Deregulation and Integration in East Asia, NBER-EASE Vol. 5, pp. 77-105, Chicago: University of Chicago Press.

Whalley, J. and Xin, X. (2010), 'China's FDI and non-FDI economies and the sustainability of future high Chinese growth', China Economic Review 21(1):123-35.

Wu, Y. (2009), China's capital stock series by region and sector, Discussion Paper No. 09.02, Business School, University of Western Australia, Perth. Available from <http://www.business.uwa.edu.au/_data/assets/pdf_ file/0009/260487/09_02_Wu.pdf $>$.

Yao, S. and Wei, K. (2007), 'Economic growth in the presence of FDI: the perspective of newly industrialising economies', Journal of Comparative Economics 35(1):211-34. 
This text taken from Deepening reform for China's long-term growth and development, edited by Ligang Song, Ross Garnaut, Cai Fang, published July 2014 by ANU Press, The Australian National University, Canberra, Australia. 